\title{
A Case of Adenosquamous Carcinoma Arising from the Tonsil
}

\author{
Nam Yoon Jung and Jong Chul Hong \\ Department of Otolaryngology-Head and Neck Surgery, Dong-A University College of Medicine, Busan, Korea
}

\section{편도에 발생한 선편평세포암 1예}

\author{
정 남 윤 · 홍 종 철 \\ 동아대학교 의과대학 이비인후-두경부외과학교실
}

\author{
Received April 8, 2017 \\ Revised June 19, 2017 \\ Accepted July 4, 2017 \\ Address for correspondence \\ Jong Chul Hong, MD, PhD \\ Department of Otolaryngology- \\ Head and Neck Surgery, \\ Dong-A University \\ College of Medicine, \\ 26 Daesingongwon-ro, Seo-gu, \\ Busan 49201, Korea \\ Tel +82-51-240-5423 \\ Fax +82-51-253-0712 \\ E-mail santa@dau.ac.kr
}

Adenosquamous cell carcinoma of tonsil is a rare lesion of head and neck and is often misdiagnosed as squamous cell carcinoma. It has a very aggressive clinical pattern. We encountered a patient with an adenosquamous cell carcinoma of tonsil and performed various treatment modalities including surgical resection, radiation therapy, chemotherapy but the patient expired two years after the first diagnosis. Such case has never been reported earlier in Korea. Herein, we present this rare case with a review of related literature.

Korean J Otorhinolaryngol-Head Neck Surg 2019;62(2):120-4

Key Words Adenosquamous carcinoma · Palatine tonsil - Radiation therapy.

\section{서 론}

선편평세포암은 선암종의 성분을 가진 편평세포암의 변이로 서 공격적인 임상 양상을 보이며 자궁, 난소, 위, 소장, 갑상선 등에서 주로 나타난다. ${ }^{1)}$ 두경부에서는 드물게 보고되고 있으 며 후두에서 가장 흔하고(26\%), 구인두(24\%), 구강(19\%), 비강 (17\%) 등의 순으로 호발한다. ${ }^{2)}$

구인두에서 발생하는 악성종양은 $90 \%$ 이상이 편평상피 세 포암종이며, 그 외에 악성 흑색종, 소타액선암종, 림프종, 소세 포암, 육종 등이 발생한다. ${ }^{3)}$ 발생 위치는 편도, 설기저부, 구인 두후벽, 연구개 등의 순으로 흔하게 나타난다.

지금까지 두경부 영역에서 국내에서 보고된 선편평세포암은 후두에서 발생한 3예, 경구개에서 발생한 1예, 구강설에 발생

This is an Open Access article distributed under the terms of the Creative Commons Attribution Non-Commercial License (http://creativecommons.org/licenses/by-nc/4.0) which permits unrestricted non-commercial use, distribution, and reproduction in any medium, provided the original work is properly cited.
한 3예, 그리고 두피에서 발생한 1 예, 설기저부에 발생한 1 예 등이 보고되었으나, 편도에 발생한 증례는 보고된 예가 없어 문헌고찰과 함께 보고하고자 한다. ${ }^{4-11)}$

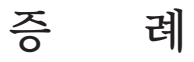

57세 남자가 내원 2개월 전부터 경부 이물감이 있어 다른 병 원 진료를 본 후 편도의 종물이 발견되어 본원으로 전원되었 다. 신체검사에서 왼쪽 편도에 $3.4 \times 2.8 \mathrm{~cm}$ 정도의 표면이 불 규칙한 돌출형 종괴가 관찰되었고(Fig. 1A), 왼쪽 경부 II 구 역에서 전이로 의심되는 $1 \times 1.5 \mathrm{~cm}$ 크기의 림프절이 촉진되었 다. 통증이나 압통은 없었으며 주변 조직과 유착된 소견은 보 이지 않았다. 왼쪽 편도에서 시행한 조직검사에서는 편평상 피세포암으로, 림프절 세침흡인검사에서는 림프절 전이로 진 단되었다. 경부 전산화단층촬영에서는 왼쪽 편도에 구인두를 폐색시키는 등밀도의 종괴 및 왼쪽 경부림프절 비대 소견이 

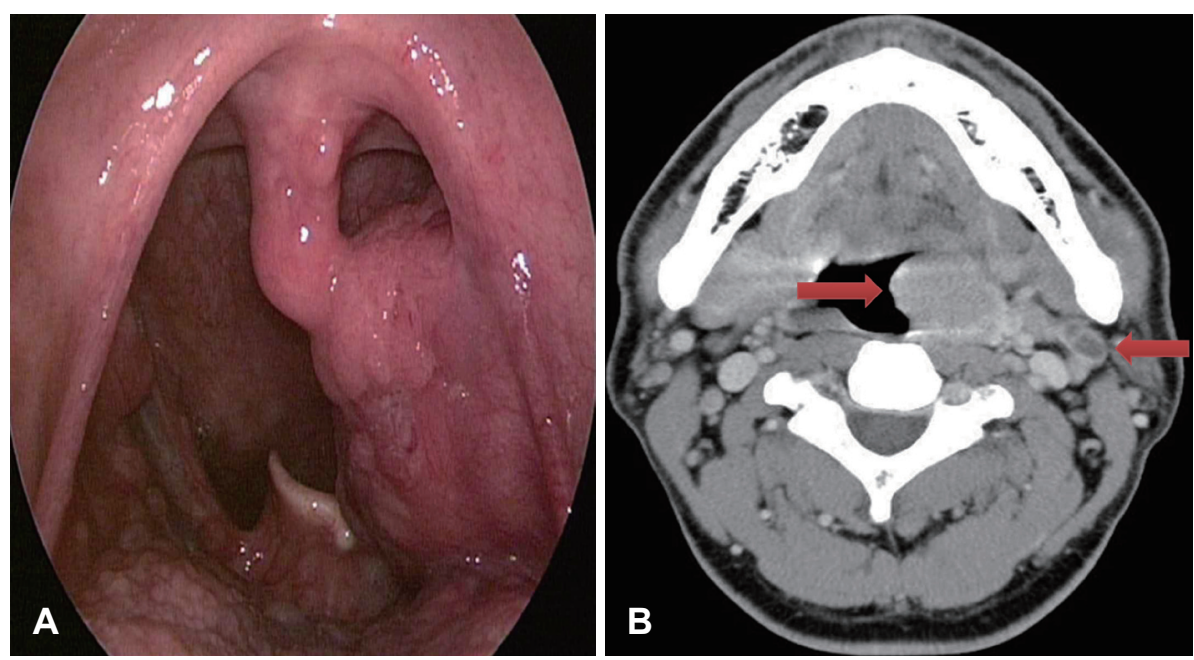

Fig. 1. About $2.8 \times 2.0 \mathrm{~cm}$ sized protruding mass is found in the left tonsil. The surface was irregular and there was no bleeding or ulcerative lesion (A). The contrast enhanced neck $\mathrm{CT}$ shows a huge isodense mass in the palatine tonsil (left arrow) and multiple lymph node enlargement (right arrow) (B).

나타났다(Fig. 1B). 양전자 방출 단층촬영에서는 왼쪽 편도에 표준섭취계수 21.53으로 측정되는 과대사 종괴가 관찰되며 왼 쪽 경부 II 구역에서 표준섭취계수 14.63 의 경한 과대사를 보 이는 림프절이 관찰되었으며 타 장기로의 전이 소견은 관찰되 지 않았다. 이상의 소견을 종합하여 cT2N1M0의 편도 편평상 피암으로 진단하고 수술을 계획하였다.

수술은 경구강 로봇절제술과 경부림프절 절제술을 시행하 였다. 먼저 경부림프절 절제술(I-V)을 시행한 후, 구강 안으로 로봇을 이용하여 원발병소를 제거한 후 동결절편검사를 통해 자유면 확보를 확인하였다. 병소를 제거한 편도와에 결손 부 위는 없었으며 지혈 후 수술을 종료하였다. 병리학적 판독 결 과 표면에 편평세포암이 존재하면서 CK7에 양성을 보이고 CK20에 음성을 보이는 시알로뮤신(sialomucin)을 포함한 종 양세포가 동시에 관찰되었기에 선편평세포암으로 진단되었다 (Fig. 2). 검체의 전·후 변연에서는 자유면이 확보되었으나 가 쪽 변연에서 병변과 접해있는 소견을 보였다. 경부림프절은 총 26 개 중 2개에서(level II) 전이가 확인되었다. 원발암의 크기 는 $2.2 \times 2 \times 1.1 \mathrm{~cm}(\mathrm{~T} 2)$ 였으며 림프절의 크기는 $2.5 \times 2 \mathrm{~cm}$ 크 기로 주변 구조물과의 유착 및 신경초 침윤, 혈관 주위 침윤 등의 소견은 없었다(Fig. 2). 이로써 병기는 pT2N1M0로 진단 할 수 있었다. 술 후 4주부터 30회에 걸친 $200 \mathrm{cGY}$ 방사선 치 료를 시행하여 총 $6000 \mathrm{cGy}$ 의 방사선을 조사하였으며 이후 외래 추적관찰하였다.

수술 후 5개월째, 입안 통증이 있어 시행한 진찰에서 왼쪽 편도와 부위에 궤양 소견이 관찰되었다(Fig. $3 \mathrm{~A}$ ). 조직검사를 시행한 결과 국소재발이 확인되어 왼쪽 편도와 광범위 절제술 후 30회에 걸쳐 총 $6130 \mathrm{cGy}$ 방사선 치료를 시행하였다. 정기 적인 외래 경과 관찰 중 수술 후 14 개월째 구강 통증과 왼쪽 경부 통증이 있어 촬영한 경부 전산화단층촬영에서 재발이 의
심되었다(Fig. 3B). 초음파 유도하 세침흡인검사를 시행하였는 데 그 결과 국소재발이 확인되었다. 환자는 추가적인 수술은 거부하여 항암화학 치료를 시작하였다. Vinorelbine, Cisplatin 항암요법 2차례, Erbitux, 5-FU, Cisplatin 항암요법 1차례, Etoposide-Cisplatin 항암요법 1차례, Cyclophosphamide, Adriamycin, Cisplatin 항암요법 1차례, Keytruda 항암요법 3차례 를 시행하였으나 별다른 반응이 없었다. 그리고 1년 7개월째 폐 전이 소견을 보였으며, 결국 2 년만에 환자는 사망하였다.

\section{고 찰}

선편평세포암은 두경부에서 흔하지 않은 종양으로, 선암종 과 편평세포암의 조직학적 소견을 모두 가지는 악성종양이며 상기도의 점막 상피에서 기원한다고 알려져 있다.5) 분명한 위 험인자는 밝혀지지 않았지만 흡연이나 음주 등의 생활습관 과 점막의 자극이나 손상 등과 연관이 있다. ${ }^{3)}$ 사람 유두종바 이러스(human papilloma virus) 8번, 10번 아형 또한 위험인자 로 여겨진다. ${ }^{3)}$

편도암은 초기에는 특별한 증상을 일으키지 않으며 환자는 비특이적인 목 통증, 연하통, 무통성 경부 종괴 등을 호소한다. ${ }^{12)}$ 진찰에서 편도의 백반증이나 만성 염증 소견만 보이기 때문 에 진단되기까지 수개월이 걸리기도 한다. 따라서 진단 당시에 는 병변이 진행된 경우가 흔하고, 경부림프절의 전이 또한 빈 번하게 발생한다. ${ }^{12}$

선편평세포암의 확진은 조직학적으로 이루어진다. 선편평 세포암은 하나의 종양 안에 편평세포암의 특징을 보이는 부 분과 선암종의 특징을 보이는 부분이 각각 분리되어 존재해 야 확진할 수 있다. ${ }^{13)}$ 특수염색을 시행하면 편평세포암종의 경우 암종배아항원(carcinoembryonic antigen)에 양성, CK7/8 
과 CK20에 음성을 보인다. 선암종의 병변은 팬사이토케라틴 (pancytokeratin), CK7/8에 양성, periodic-acid-Schiff stain 등의 특수염색을 시행하면 시알로뮤신을 볼 수 있다. ${ }^{13)}$ 본 증
례의 검체에서는 $\mathrm{CK} 7$ 에 양성, $\mathrm{CK} 20$ 에 음성을 보였으며 시알 로뮤신 또한 관찰할 수 있었다. 주로 편평세포암의 특징을 보 이는 부분은 주로 종양의 표면에 위치하며 선암종의 특징을

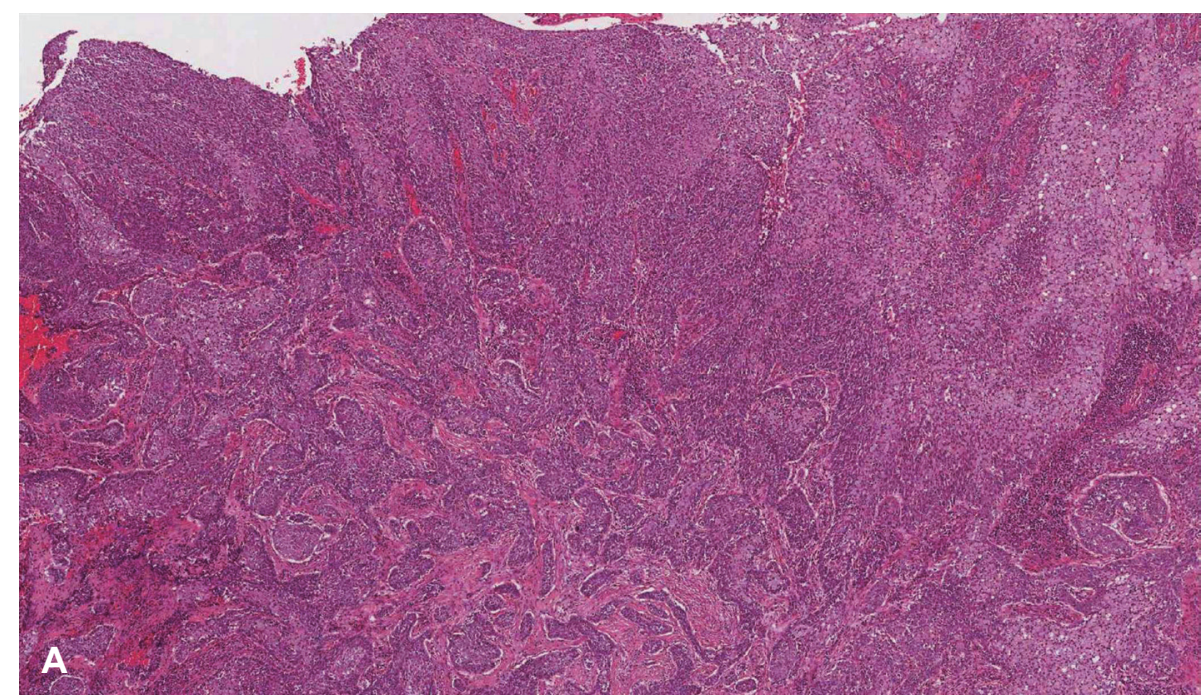

Fig. 2. The resected specimen findings. The lower power view of the tonsil shows carcinomatous change of the surface epithelium (top) with stromal invasion by tumor nests. The anterior and posterior resection margin is free of tumor, but the lateral margin is abuts on tumor $(\mathrm{H}-$ $E, \times 20)(A)$. The high power view of the surface epithelium is replaced by adenosquamous carcinoma, composed of malignant squamous epithelium punctated by mucin containing cells (arrows) $(\mathrm{H}-\mathrm{E}, \times 200)(\mathrm{B})$. The mucin stain shows red colored mucin containing cell nests (arrows) in the surface tumor tissue (mucicarmin stain, $\times 200)(C)$.
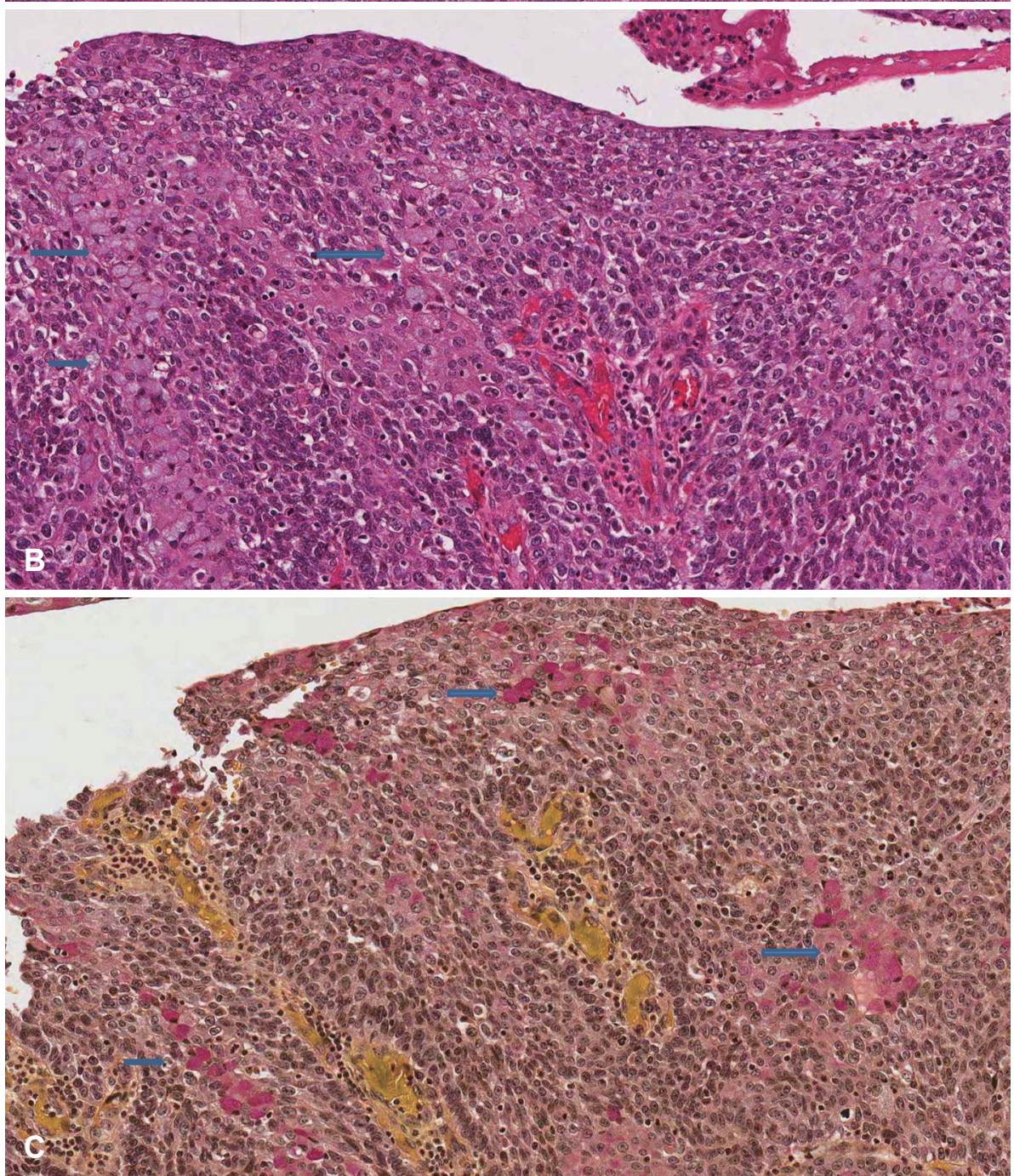
Fig. 3. Postoperative state of the left tonsillar fossa. There is an ulcerative lesion at the left tonsillar fossa (A). The contrast enhanced neck CT shows a heterogenous and low density lesion in the left neck which suggested the local recurrence of the adenosquamous carcinoma (B).
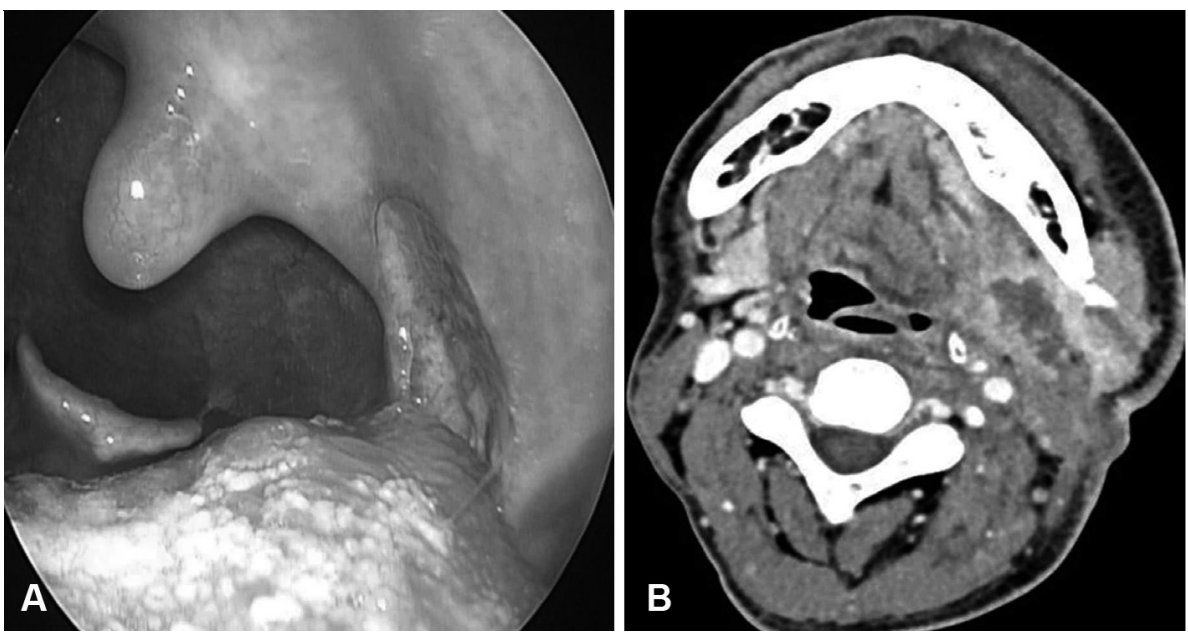

보이는 부분은 더 깊숙한 곳에 위치하기 때문에 세침흡인검 사 또는 불완전한 조직검사 검체 채취로 인해 편평세포암으 로 오진되는 경우도 있다. ${ }^{14)}$ 본 증례에서도 외래에서 시행한 조직검사에서는 편평세포암으로 진단되었으며 근치적 수술 후에 선편평세포암으로 진단되었다. 원발 부위와 경부림프절 전이 및 원격 전이를 판단하기 위해서는 전산화단층촬영, 자 기공명영상, 양전자 방출 단층촬영, 골 스캔 검사 등의 영상 학적 검사가 필요하다. ${ }^{14}$

치료법에 대한 대규모 무작위 연구결과는 없는 실정이므로, 여러 과의 협진을 통해 최상의 치료 방침을 정해야 한다. 치료 를 결정하기 위해서는 종양의 형태, 병기, 예상 침습 경로, 하악 골 침윤 등을 고려해야 한다. 두경부에 발생한 선편평세포암 은 선암이나 편평세포암보다 공격적인 성향을 보이며 예후 또한 나쁘다. 또한 림프절 전이 여부가 주된 예후인자이기 때 문에 주로 조기에 원발 부위의 근치적인 수술적 절제 및 경부 림프절 절제술, 수술 후 항암제-방사선 치료 동시요법 등이 추천된다. ${ }^{15)}$ 경구강 로봇절제술은 기존의 수술법들에 비해 기능적 후유증이 적으면서 치료 결과는 유사한 것으로 나타 났다. ${ }^{16)}$ 단독 항암요법은 일차적 치료방법으로는 효과적이지 못하다고 알려져 있으며, 방사선 치료 또한 과거부터 두경부 암의 치료에서 중요한 역할을 해왔지만 최근에는 진행암에 서 항암제-방사선 치료 동시요법이 방사선 단독치료군보다 유의한 국소재발률 감소와 생존율 증가를 보이는 것으로 보 고되었다. ${ }^{15,17)}$ 본 증례에서는 근치적 수술 후 방사선 치료를 하였으나 국소재발이 발생하였다. 이는 수술 중 동결절편검 사를 통해 자유면 확보를 확인하였으나 병리검사상 가쪽 변연 이 종양과 매우 가까운 것으로 판독되어 잔류암의 가능성도 배제할 수 없을 것으로 보인다. 이후 재수술 및 추가적인 방사 선 치료를 하였지만 다시 재발 및 원격 전이가 발생하였고 항 암 치료를 하였으나 질병의 경과를 바꾸지 못하였다. 수술 후
항암제-방사선 치료 동시요법을 했더라면 더 나은 결과가 나 오지 않았을까 하는 생각이 든다.

선편평세포암은 편평세포암보다 공격적인 성향을 나타내 기 때문에 진단 시 주변 조직에 현저한 침윤 소견이나 국소적 또는 원격 전이 소견을 보이는 경우가 많다. ${ }^{12)}$ 두경부의 편평 세포암은 $10 ~ 15 \%$ 의 환자에서 원격 전이를 보이며 $50 \%$ 의 5 년 생존율을 나타낸다. 반면에 선편평세포암은 3년 생존율 50\%, 5년 생존율 20\%, 10년 생존율 0\%를 보이며, $40 \%$ 의 환자가 30 개월 안에 사망한다. ${ }^{18)}$ 림프절 전이 여부가 중요한 예후인자 인데 본 증례도 림프절 전이가 있었으며 재발 및 원격 전이가 발생하였고 진단 후 2 년만에 사망하여 질병의 공격적인 성향 을 알 수 있었다. ${ }^{15}$

편도를 포함한 두경부에 발생한 선편평상피암은 보고된 증 례가 적을 뿐만 아니라 조직학적 오진 가능성 및 공격적인 성 향으로 인한 높은 사망률로 인해 치료에 대한 연구가 충분히 이루어지지 않은 상태이다. 선편평상피암의 치료를 위해서는 선편평상피암에 대한 연구가 더 많이 이루어져야 할 것이다. 본 증례에서는 원발 부위의 근치적 절제술, 경부 림프적 절제 술 및 방사선 치료, 항암 화학요법 등 여러 가지 치료방법을 동원하였으나 국소재발, 원격 전이 등의 소견을 보여, 정기적 인 추적관찰의 필요성을 시사한다. 또한 현재 사용되고 있는 치료방법 이외에도 새로운 치료방법의 개발 또는 발견이 이루 어진다면 적극적으로 적용해 보아야 할 것이다.

\section{REFERENCES}

1) Gerughty RM, Hennigar GR, Brown FM. Adenosquamous carcinoma of the nasal, oral and laryngeal cavities. A clinicopathologic survey of ten cases. Cancer 1968;22(6):1140-55.

2) Kass JI, Lee SC, Abberbock S, Seethala RR, Duvvuri U. Adenosquamous carcinoma of the head and neck: Molecular analysis using CRTC-MAML FISH and survival comparison with paired conventional squamous cell carcinoma. Laryngoscope 2015; 
125(11):E371-6.

3) Funk GF, Karnell LH, Robinson RA, Zhen WK, Trask DK, Hoffman HT. Presentation, treatment, and outcome of oral cavity cancer: a national cancer data base report. Head Neck 2002;24(2):165-80.

4) Choi CY, Chung JB, Ahn MS, Koh KS, Lim HJ. A case of adenosquamous cell carcinoma of the larynx. Korean J Otorhinolaryngol-Head and Neck Surg 1987;30(1):165-8.

5) Kim YM, Kim KS, Lee JY, Chu YC. A case of adenosquamous' carcinoma of the larynx. Korean J Otorhinolaryngol-Head and Neck Surg 1993;36(6):1349-55.

6) Kwon SW, Choi SH, Choi YS, Sohn KR. A case of adenosquamous carcinoma of the larynx. Korean J Otolaryngol-Head Neck Surg 2000;43(9):1005-7.

7) Kim YM, Cho JI, Lee SJ, Kim JM. A case of adenosqumous carcinoma ex pleomorphic adenoma of hard palate. Korean $\mathrm{J}$ Otolaryngol-Head Neck Surg 2001;44(11):1231-4.

8) Ko JS, Kim JP, Park JJ, Woo SH. A Case of Adenosquamous Carcinoma of the Posterior Occipital Scalp. Korean J Otorhinolaryngol-Head Neck Surg 2012;55(2):123-7.

9) Lee DK, Kim EC, Min SK, Um IW, Kweon HD, Bang MH. A case of adenosquamous cell carcinoma involving submucosal gland and tongue. Maxillofac Plast Reconstr Surg 1994;16(2):196-201.

10) Cho YA, Yoon HJ, Hong SD, Lee JI, Hong SP. Adenosquamous carcinoma of the oral cavity: case report. Kor J Oral Maxillofacial Pathol 2009;33(5):283-6.
11) Jo KS, Lee EJ, Hong SH, Hong JC. A case of adenosquamous carcinoma arising from the base of tongue. Korean J Otorhinolaryngol-Head Neck Surg 2014;57(10):720-2.

12) Choi EC, Kim ES, Kim JS, Hong WP. Surgical treatment of squamous cell carcinoma of the tonsil. Korean J Otorhinolaryngol-Head Neck Surg 1996;39(1):57-68.

13) Alos L, Castillo M, Nadal A, Caballero M, Mallofre C, Palacin A, et al. Adenosquamous carcinoma of the head and neck: criteria for diagnosis in a study of 12 cases. Histopathology 2004;44(6):570-9.

14) Lee SY, Choi EC. Treatment of adeno-squamous cell carcinoma at the posterior tongue via median glossotomy approach. Korean J Otorhinolaryngol-Head Neck Surg 2016;59(7):532-6.

15) Satomi T, Kohno M, Hasagawa O, Enomoto A, Abukawa H, Chikazu $\mathrm{D}$, et al. Adenosquamous carcinoma of the tongue: clinicopathologic study and review of the literature. Odontology 2017;105(1):127-35.

16) Dias FL, Walder F, Leonhardt FD. The role of transoral robotic surgery in the management of oropharyngeal cancer. Curr Opin Oncol. In press.

17) Cognetti DM, Weber RS, Lai SY. Head and neck cancer: an evolving treatment paradigm. Cancer 2008;113(7 Suppl):1911-32.

18) Keelawat S1, Liu CZ, Roehm PC, Barnes L. Adenosquamous carcinoma of the upper aerodigestive tract: a clinicopathologic study of 12 cases and review of the literature. Am J Otolaryngol 2002;23 (3):160-8. 